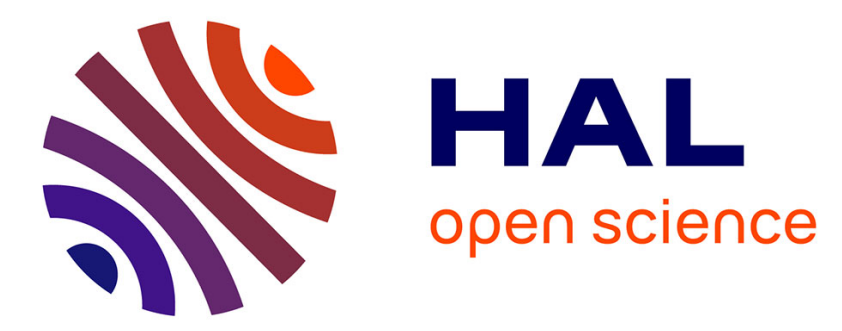

\title{
Bacterial diversity on stainless steel surfaces of egg processing companies and potential of selected isolates to spoil liquid whole egg products
}

C. Techer, Sophie Jan, Fabienne Gonnet, Noel Grosset, Michel Gautier, Florence Baron

\section{To cite this version:}

C. Techer, Sophie Jan, Fabienne Gonnet, Noel Grosset, Michel Gautier, et al.. Bacterial diversity on stainless steel surfaces of egg processing companies and potential of selected isolates to spoil liquid whole egg products. Journal of Applied Microbiology, 2019, 127, 10.1111/jam.14403 . hal-02284248

HAL Id: hal-02284248

https://institut-agro-rennes-angers.hal.science/hal-02284248

Submitted on 17 Sep 2019

HAL is a multi-disciplinary open access archive for the deposit and dissemination of scientific research documents, whether they are published or not. The documents may come from teaching and research institutions in France or abroad, or from public or private research centers.
L'archive ouverte pluridisciplinaire HAL, est destinée au dépôt et à la diffusion de documents scientifiques de niveau recherche, publiés ou non, émanant des établissements d'enseignement et de recherche français ou étrangers, des laboratoires publics ou privés. 
ORIGINAL ARTICLE

\title{
Bacterial diversity on stainless steel surfaces of egg processing companies and potential of selected isolates to spoil liquid whole egg products
}

\author{
C. Techer (D), S. Jan, F. Gonnet, N. Grosset, M. Gautier and F. Baron \\ Equipe Microbiologie, Agrocampus Ouest, Centre de Rennes, INRA, UMR1253, Science et Technologie du Lait et de I'CFuf, Rennes, France
}

\section{Keywords}

adhesion, Bacillus, biofilm, egg product, spoilage, stainless steel surfaces.

\section{Correspondence}

Florence Baron, Agrocampus Ouest, INRA, UMR1253 Science et Technologie du Lait et de I'CFuf, 65 rue de Saint Brieuc, 35042 Rennes, France.

E-mail: florence.baron@agrocampus-ouest.fr

2019/0669: received 9 October 2018, revised 19 July 2019 and accepted 23 July 2019

doi:10.1111/jam.14403

\begin{abstract}
Aims: To assess the bacterial diversity in the French egg processing industry and to explore the adhesion and spoilage potential of selected bacteria.

Methods and Results: Sterile stainless steel chips were suspended for 2 months inside the pipelines of seven egg processing companies, before and after the pasteurizer, at warm and cold seasons. After exposure, the bacterial diversity was assessed by $16 \mathrm{~S} r D N A$ sequencing. The 231 collected isolates were mainly facultative anaerobic Gram positive bacteria, such as Streptococcus, Staphylococcus, Bacillus and Kocuria. Sixty-five representative isolates were further characterized in vitro regarding the potential for adhesion and egg product spoilage. A high diversity was observed from one genus to another. Kocuria and Rothia isolates showed significantly higher adhesion than the isolates of the other genera. Only the isolates belonging to the genera Bacillus and Lysinibacillus, associated with high enzymatic activities on a solid eggbased medium, were able to induce spoilage of liquid whole egg.

Conclusions: Bacteria collected on stainless steel surfaces placed in egg processing industries could be associated to liquid egg product spoilage.

Significance and Impact of the Study: This study provides new insights on the bacterial contamination in egg processing companies and represents a first step for the effective control of undesirable bacteria in liquid egg products.
\end{abstract}

\section{Introduction}

With $14 \cdot 3$ billion eggs produced in 2017, France remains the first European producer (Itavi 2018). Approximately, $40 \%$ of these eggs are processed into egg products (Anton et al. 2016). These products, resulting from the breaking of shell eggs, are sold in the form of egg yolk, egg white or whole egg (mixture of egg yolk and egg white). Egg products are used by food artisans, restaurants, industrial catering and residential facilities and by the food industry (Lechevalier et al. 2011; Anton et al. 2016). The latter is the main user due to the various functionalities the egg products offer (colouring, thickening, emulsifying and gelling properties). Although the content of shell eggs is generally sterile under safe conditions of breeding, the process of egg product manufacturing induces a systematic contamination due to the unavoidable contact with eggshells (Baron and Jan 2011; EFSA, 2014; Techer et al., 2014a). Moreover, once broken, the egg lost, at least part of its natural antimicrobial defences (Baron and Jan 2011). Considering their nutritious composition, whole egg and egg yolk are ideal environments for the development of micro-organisms. They also make particularly sensitive the uncooked or lightly cooked finished products in which they are used as ingredients, such as pastry, sea-food products, meat products or dairy products. In order to ensure the best microbial stabilization of liquid egg products, the French egg product industry submitted whole egg and egg yolk to treatments between 60 and $65^{\circ} \mathrm{C}$ for $2-6 \mathrm{~min}$ and to milder treatments for liquid egg white, that is, between 55 and $57^{\circ} \mathrm{C}$ for $5-6$ min (Baron and Jan 2011; EFSA 2014). After pasteurization, the liquid egg products are conditioned, stored and delivered at refrigerated 
temperatures (usually at $4^{\circ} \mathrm{C}$ ). At this temperature, the shelf-life varies from few weeks to 3 months (Anton et al. 2016; Baron and Jan 2011).

The major safety preoccupation of the sector remains the contamination by Salmonella, even if it is now under the control of breeding surveillance and of effective pasteurization processes (EFSA 2014). Nevertheless, the low heattreatments usually applied to liquid egg products, owing to their high heat-sensitivity, are inefficient to kill heat-tolerant bacteria such as spore-forming bacteria or Enterococci (Jan et al. 2011; Techer et al. 2015). Therefore, the manufacturers have to control undesirable bacteria, particularly spoilage flora resisting the pasteurization processes. These bacteria can be found in the product itself or adhere on the surface of the stainless steel pipelines where they can form biofilms. The adhesion/attachment of micro-organisms to industrial surfaces is a critical step in biofilm development. This latest, frequently observed in the food industry, provides a protected mode of growth that allows micro-organisms to resist the hostile and fluctuating conditions they encounter through the food process and the cleaning and disinfection methods (variation of $\mathrm{pH}$, temperature, nutrients, shear forces and presence of disinfectants). It is generally accepted that disinfection is more effective on planktonic micro-organisms than on micro-organisms within a biofilm (Houdt and Michiels 2010) and that the release of micro-organisms from biofilms can be a source of food contamination and food spoilage. The spoilage flora can lead to technological and/or sensorial issues (coagulation, changes in colour or in flavour) due to the production of hydrolytic enzymes such as lipases or proteases, even at low temperature (Techer 2015).

The purpose of this study was to evaluate, in seven egg processing companies and at two consecutive seasons (warm and cold), (i) the diversity of the micro-organisms attached to the stainless steel surfaces in the pre- and postpasteurization pipelines, and (ii) the in vitro stainless steel adhesion and whole egg spoilage properties of the recovered isolates.

The results of this study should significantly improve the understanding of the behaviour of specific adherent bacteria likely to cause liquid whole egg spoilage. It represents a first step for the effective control of undesirable biofilms, which is of great concern for reducing the economic losses due to bacterial spoilage in this food industrial sector.

\section{Materials and methods}

Recovery of bacteria from stainless steel surface of the egg processing companies

Stainless steel chips (quality $304 \mathrm{~L}, 2 \mathrm{~mm}$ thick, $1 \mathrm{~cm} \times 3 \mathrm{~cm}$ ) were provided by Bretagne Laser (Guer,
France). After immersion in RBS 35 detergent solution (Sigma-Aldrich, Saint Quentin Fallavier, France) at 2\% v/ $\mathrm{v}$ in distilled water, the chips were rinsed five times ( 5 min per rinsing) with distilled water at $50^{\circ} \mathrm{C}$ and five times with ultrapure water (distilled water treated with Sartopore 0.2 mm; Arium 611, Sartorius, Germany) at ambient temperature (between 20 and $25^{\circ} \mathrm{C}$ ). They were then autoclaved for $20 \mathrm{~min}$ at $120^{\circ} \mathrm{C}$ and addressed under sterile conditions to each of the seven French egg product companies. Each company had previously manufactured its own fixation system to ensure the sustainable attachment of the chips inside the pipelines. Sleeves were inserted into the pipes of the companies. Inside these sleeves, the coupons were fixed with a flat rod crossing the sleeves. The chips were suspended at two levels, before and after the pasteurizer, and at consecutive warm and cold seasons. After 2 months, the chips were aseptically removed, placed individually in tubes containing $6 \mathrm{ml}$ of sterile trypton salt $(0 \cdot 1 \%$ trypton; AES Laboratoire, Combourg, France; $0 \cdot 85 \% \mathrm{NaCl}$; Labogros, Buchs, France) and transported at $4^{\circ} \mathrm{C}$ to our laboratory, within $24 \mathrm{~h}$. The fixation of the chips inside the pipelines as well as their removal were carried out on the same day in each company, after the last washing of a cleaning and disinfection procedure. In the laboratory, successive aseptic treatments were performed in order to recover bacteria present on the stainless steel surface. For the recovery, we have distinguished two bacterial populations which are referred to as 'weakly' and 'highly' adherent cells in this study. Weakly adherent cells were recovered in a tryptone salt solution in which the chips were immersed. The chips were held in place while the solutions were transferred into new sterile tubes (collection tubes). A new $6 \mathrm{ml}$ volume of tryptone salt was added on each chip and the tubes were vortexed to suspend the remaining cells. This step was repeated twice and the two washing solutions were transferred into the respective collection tubes (final volumes of around $18 \mathrm{ml}$ ). For recovering the strongly adherent cells, $6 \mathrm{ml}$ of sterile tryptone salt was added in each tube containing a washed chip and the tubes were immersed in a sonication bath for $15 \mathrm{~min}$ at $25 \mathrm{kHz}$ and at ambient temperature. Each chip was then transferred with the tryptone salt solution into a Petri dish. Each face of the chip was scraped for 1 min with a sterile scraper (Dutscher, Brumath, France) in order to recover the highly adherent cells. For each repetition, a sterile scraper was used. Scraping was performed with horizontal, vertical and circular movements. The solutions containing the recovered cells were transferred into new sterile tubes for analysis (Jan et al. 2011; Techer et al. 2014a, 2014b).

The adherent cell suspensions (weakly and highly adherent cells) were submitted to serial dilutions in tryptone salt 
and subsequent plating onto BHI-YE agar (3.7\% Brain Heart Infusion $(\mathrm{m} / \mathrm{v})$; Scharlau, Sentmenat, Spain; $1 \%$ yeast extract; $1.5 \%(\mathrm{~m} / \mathrm{v})$ agar; Merck, Darmstadt, Germany) and incubated for $1-7$ days at $30^{\circ} \mathrm{C}$, under aeroand anaerobic conditions. After incubation, the colony forming units (CFU) were counted. For each sample analysed, colonies showing different macroscopic (size, shape, colour, texture and elevation) and microscopic criteria, were isolated, purified and further identified. This selection resulted in the creation of a bacterial collection comprising 231 colonies. The isolates were subcultured onto BHI-YE at $30^{\circ} \mathrm{C}$ under aero- and anaerobic conditions for $24-48 \mathrm{~h}$. For each colony, the bacteria were observed under phase contrast microscopy in order to check the purity of the colony before identification. Each pure isolate was kept frozen in $50 \%(\mathrm{v} / \mathrm{v})$ glycerol at $-20^{\circ} \mathrm{C}$.

\section{Investigation on the industrial practices}

A survey containing about 40 items was submitted to each company in order to provide additional information on the industrial practices. The resulting data set contained information on the sampling season (cold or warm), on the characteristics of several process rooms and equipment (process room temperature, type and age of the pasteurizer and of the pipelines), on the localization of the chips and on the type and localization of the fixation systems. The type of egg product that had been treated during the period of the experiment ( 2 months), the flow rates and the temperatures inside the pipelines, were also registered, as well as the cleaning and disinfection procedures that were carried out during this period (type of products, temperatures, frequency).

\section{Identification of adherent harvested cells}

Isolates were identified by sequencing the $16 \mathrm{~S}$ rDNA gene region. Bacterial cells were cultivated for $18 \mathrm{~h}$ at $30^{\circ} \mathrm{C}$ in BHI-YE. DNA extraction was performed by mixing $5 \mathrm{ml}$ of culture with $300 \mu \mathrm{l}$ of $25 \%$ (w/v) Chelex beads (Sigma-Aldrich). After centrifugation at $5700 \mathrm{~g}$ for $7 \mathrm{~min}$ at $4^{\circ} \mathrm{C}$, the pellet was resuspended in $200 \mu \mathrm{l}$ water (Sigma-Aldrich) and incubated at $100^{\circ} \mathrm{C}$ for $10 \mathrm{~min}$. The supernatant was purified by two successive centrifugations for $7 \mathrm{~min}$ at $5700 \mathrm{~g}$ and $4^{\circ} \mathrm{C}$. The DNA concentration was assayed using the Nanodrop ND-1000 (Nanodrop Technologies, Wilmington, DE). About 50 ng DNA was added to the reaction mixture. The latter was composed of $0.18 \mathrm{mmol} \mathrm{l}^{-1}$ dNTPs (Eurogentec, Seraing, Belgium), $0 \cdot 7 \mu \mathrm{mol} \mathrm{l}^{-1}$ of each $16 \mathrm{~S}$ primer (5'-GCCAGCAGCCGCGGTAA- ${ }^{\prime}$ as forward degenerate primer and $5^{\prime}$-GACGGGCGGTGTGTAC- $3^{\prime}$ as reverse primer), $53.6 \mathrm{U} \mathrm{ml}^{-1}$ AmpliTaq polymerase and 0.9X AmpliTaq buffer (Biolabs, Evry, France). PCR was performed using the following program in the iCycler optical module 584BR thermocycler (BioRad, Marnes-laCoquette, France): initial denaturation at $95^{\circ} \mathrm{C}$ for $4 \mathrm{~min}$; 30 cycles at $95^{\circ} \mathrm{C}$ for $30 \mathrm{~s}, 50^{\circ} \mathrm{C}$ for $30 \mathrm{~s}, 72^{\circ} \mathrm{C}$ for $30 \mathrm{~s}$; followed by a final extension at $72^{\circ} \mathrm{C}$ for $7 \mathrm{~min}$. Purification and sequencing were performed by GATC Biotech AG (Konstanz, Germany) using the following primer: $5^{\prime}$-GCC AGCAGCCGCGGTAA-3'. DNA sequences were compared with available sequences deposited in GenBank (http:// www.ncbi.nlm.nih.gov/Genbank) using nucleotide-nucleotide Basic Local Alignment Search Tool (BLAST) for nucleotides (blastn) alignments accessed from the website (http://www.ncbi.nlm.nih.gov/BLAST/). The similarity index considered for identification was $>96 \%$.

\section{In vitro adhesion of harvested cells on stainless steel}

The isolates were pregrown in $\mathrm{BHI}-\mathrm{YE}$ at $30^{\circ} \mathrm{C}$ for $18 \mathrm{~h}$. The adhesion of each isolate was studied on 2-mm thick and 15mm diameter 3041 stainless steel chips (Bretagne Laser). Chips were washed and autoclaved by the same procedure as that used for the chips installed in the industrial pipelines $(\S 2 \cdot 1)$. After washing and sterilization, the chips were individually transferred into the bottom of the wells of a 24-well microplate. Cell suspensions were then diluted in $9 \mathrm{~g} \mathrm{l}^{-1}$ $\mathrm{NaCl}$ until the $10^{-2}$ dilution. Three hundred microlitres of the recent dilution was then added to each well. After $2 \mathrm{~h}$ incubation at $30^{\circ} \mathrm{C}$, the cell suspensions were removed and the chips maintained in the wells were rinsed twice with $9 \mathrm{~g} \mathrm{l}^{-1} \mathrm{NaCl}$ in order to remove nonadhering cells. After addition of $300 \mu \mathrm{l}$ of $9 \mathrm{~g} \mathrm{l}^{-1} \mathrm{NaCl}$, the adherent cells were scraped for $1 \mathrm{~min}$ with a sterile scraper (Dutscher). The number of initial and adherent cells was enumerated on BHI-YE agar at $30^{\circ} \mathrm{C}$ for $24 \mathrm{~h}$, using a plate counting micromethod (Baron et al. 2006). The results were respectively expressed in log CFU per $\mathrm{ml}$ and in log CFU per $\mathrm{cm}^{2}$. For comparison between isolates, the ratio between the concentration of adherent cells and the initial cell concentration was calculated for each isolate $\left(\mathrm{cm}^{2} \mathrm{ml}^{-1}\right)$.

To ensure the reproducibility of the adhesion tests, the Bacillus cereus group strain $\mathrm{C} 43$, provided by Guinebretière et al. (2002), and the B. cereus group strain BW1, isolated from a spoiled liquid whole egg product (Baron et al. 2007), for which the adhesion on stainless steel was already determined (Jan et al. 2011), were used as internal standards.

\section{Spoilage potential}

Growth ability at $10^{\circ} \mathrm{C}$ in optimum medium

Before each experiment, frozen isolates were twice cultivated in BHI-YE. Serial decimal dilutions of the pure 
cultures were carried out in trypton salt in order to reach an initial bacterial concentration of around $10^{3} \mathrm{CFU}$ per $\mathrm{ml}$ of BHI-YE. Inoculum was checked using a plate counting micro-method (Baron et al. 2006). The mixtures were incubated at $10^{\circ} \mathrm{C}$ for 21 days. After the incubation period, enumeration was performed on BHI-YE agar at $30^{\circ} \mathrm{C}$ for $24 \mathrm{~h}$, using plate counting micro-method.

\section{Whole egg spoilage at $10^{\circ} \mathrm{C}$}

The spoilage potential of each isolate was monitored in sterile liquid whole egg at $10^{\circ} \mathrm{C}$. The sterile liquid whole egg was prepared according to Baron et al. (2007). Briefly, eggs were rubbed with absorbent paper to clean the shells and checked to detect any cracks. Eggshell surface was sterilized with $70 \%$ alcohol, and quick flaming. Under sterile conditions, eggshell was cracked and whole egg content was aseptically collected into a sterile beaker, and then homogenized with a homogenizer DI25 Basic (Ika, Grosseron, France) at $9500 \mathrm{rev} \mathrm{min}^{-1}$ for $1 \mathrm{~min}$. Sterility was systematically checked: $1 \mathrm{ml}$ whole egg was poured into a Petri dish with trypton soy agar (VWR International, Strasbourg, France) and incubated overnight at $37^{\circ} \mathrm{C}$ before confirmation of the absence of colonies. Liquid whole egg was then artificially contaminated with a suspension of each isolate, according to the procedure of inoculation previously described in Techer et al. (2014a, 2014b). Visual observations of inoculated whole egg were made every day until total coagulation, that is, transformation of the sterile liquid whole egg product into a white slurry cream (or until 21 days if no coagulation occurred). Results were expressed as absence or presence of coagulation and as the delay necessary for reaching this state. For each experiment, the absence of egg coagulation was checked in a negative control for which sterile liquid whole egg was incubated without previous inoculation.

Bacteria exhibiting a spoilage potential were further characterized based on their enzymatic activities in whole egg-based medium. Total enzymatic activities, including protease, lipase and phospholipase activities, were assayed according to Jan et al. (2014). Briefly, $5 \mu \mathrm{l}$ of an overnight bacterial culture was spotted onto the surface of a solid agar medium containing 2.6\% whole egg. Plates were incubated at $10^{\circ} \mathrm{C}$. After 5,10 and 15 days of incubation, photographs were taken and the area of the colonies and of the halos were measured using the ImageJ software (ver. 1.52). Results were expressed as specific enzymatic activities (ratio between the halo area and the colony area) as a function of time.

\section{Statistical analyses}

The statistical analyses and boxplot representation were performed using the $\mathrm{R}$ software (ver. 2.13.0). In vitro adhesion assays were performed independently on three different occasions with three replicates in each trial. The adhesion results were compared using a Tukey's HSD post hoc test with $\alpha=0.5$ and $P \leq 0.05$ considered as significant. Spoilage assays (growth, visual whole egg spoilage monitoring, enzymatic activities) were performed in three independent experiments. Average values \pm SD are presented.

\section{Results}

Diversity of the cells recovered from the chips suspended inside the industrial pipelines

Considering the level of the bacterial population adhering on the stainless steel chips, two types of companies were highlighted. The first type comprises the companies 3, 5 and 6 , which harboured heavily contaminated chips, that is, those containing 17-27 colonies per $\mathrm{cm}^{2}$. The second type comprised the companies 1, 2, 4 and 7 in which the chips were slightly contaminated, that is, contained no more that $0-7$ colonies per $\mathrm{cm}^{2}$. However, we failed to count the cells harvested from the chips with the plate counting method. The counts were not reliable (noncompliance with the tenfold dilution factor), suggesting that the cells were present in clusters inside the suspensions, even after sonication. The colonies appeared only after 2 days of incubation at $30^{\circ} \mathrm{C}$ in BHI-YE agar and after up to 7 days for some of them. This phenomenon suggests the presence of stressed cells, probably due to the fact that the chips were recovered after a procedure of cleaning and disinfection.

A total of 231 isolates, representative of the diversity of the colonies recovered on the agar plates, were selected for the two different sampling points of the seven companies. This collection was composed of 98 and 133 weakly and highly adherent isolates respectively. The genera identified are presented in Table 1. The harvested cells were mainly facultative anaerobic Gram positive bacteria. The most encountered genera were Streptococcus sp., Staphylococcus sp., Bacillus sp. and Kocuria sp. These bacteria were present in at least five of the seven companies which participated in the study (Table 1). Generally, these bacteria corresponded to both weakly and highly adherent cells and were detected during the cold and the warm season, on the chips localized before and after the pasteurizer (Table 1). Microbacterium and Rothia sp. were identified in three egg processing companies. Microbacterium sp. was identified as weakly and highly adherent, before and after the pasteurizer and at both seasons. Rothia sp. was present on the chips placed before and after the pasteurizer. It corresponded to highly adherent cells recovered only at the cold season (Table 1). 
Corynebacterium sp., Dietzia sp., Enterococcus sp. and Microcococcus sp. were identified in two of the seven companies, at both seasons and generally before and after the pasteurizer, except for Dietzia sp. which was only detected before the pasteurizer (Table 1). Other genera, such as Brevibacterium sp., Citrobacter sp., Leucobacter sp., Lysinibacillus sp., Okadaella sp., Rhodococcus sp., Shigella sp. and Tessaracoccus sp., were identified in only one company. Most of them corresponded to highly adherent cells. Their presence depended on the season or on the location of the chips (Table 1 ).

When possible, the species were identified: (i) for Streptococcus, the species S. parasanguinis, S. cristatus, S. salivarius, S. mitis, S. vestibularis, S. oralis, S. thermophilus and S. sanguinis; (ii) for Staphylococcus, the species $S$. pasteuri and S. saprophyticus; (iii) for Micrococcus, the species M. luteus; (iv) for Rothia, the specie: R. mucilaginosa; (v) for Microbacterium, the species M. lacticum and M. testacum; for Bacillus, the B. cereus group, and the species B. licheniformis and B. subtilis; for Lysinibacillus, the species L. fusiformis and L. sphaericus.

The bacterial genera recovered from the stainless steel chips are presented in Fig. 1. Except the chips of the companies 1 and 2, on which no bacteria were recovered, the presence of one or several genera was generally observed. Only one genus was observed on two chips of the company 2 (before and after the pasteurizer, at the warm season), on one chip of the company 4 (before the pasteurizer and at the cold season) and on two chips of the company 7 (before the pasteurizer at the cold season and after the pasteurizer at the warm season). The companies 3 and 5 exhibited a higher diversity, with three to seven different genera recovered on the chips at both locations and at both seasons (Fig. 1).

\section{Investigation on the industrial practices}

The survey analysis shows a high diversity of industrial practices from one company to another. Egg yolk and whole egg have circulated in the pipelines of all the companies during the time of experimentation. In some companies, liquid egg white has also circulated. In three companies, a slight percentage of sugared or salted egg products has also been processed. Concerning cleaning and disinfection procedures, they also varied according to companies.

Among all the recovered isolates, we choose to further study the highly adherent ones, belonging to the genera that were common to at least three companies and that were present both before and after pasteurization, that is, Streptococcus, Staphylococcus, Bacillus, Kocuria, Microbacterium and Rothia. In addition, we choose to investigate the behaviour of Lysinobacillus, originally

Table 1 Bacterial genera recovered from the stainless steel chips placed for 2 months in the pipelines of seven French egg processing companies (C1-C7), at two seasons (cold and warm), and before and after the pasteurizer

\begin{tabular}{|c|c|c|c|c|c|c|c|c|}
\hline \multirow[b]{2}{*}{ Bacterial genus } & \multirow{2}{*}{$\begin{array}{l}\text { Number } \\
\text { of isolates }\end{array}$} & \multirow{2}{*}{$\begin{array}{l}\text { Number of } \\
\text { companies }\end{array}$} & \multicolumn{2}{|c|}{ Type of adherent cells ${ }^{*}$} & \multicolumn{2}{|c|}{ Season } & \multicolumn{2}{|c|}{ Pasteurization } \\
\hline & & & Weakly & Highly & Cold & Warm & Before & After \\
\hline Streptococcus & 44 & 6 & + & + & + & + & + & + \\
\hline Staphylococcus & 44 & 6 & + & + & + & + & + & + \\
\hline Bacillus & 39 & 5 & + & + & + & + & + & + \\
\hline Kocuria & 19 & 5 & + & + & + & + & + & + \\
\hline Microbacterium & 12 & 3 & + & + & + & + & + & + \\
\hline Rothia & 11 & 3 & & + & + & & + & + \\
\hline Corynebacterium & 27 & 2 & + & + & + & + & + & + \\
\hline Dietzia & 4 & 2 & & + & + & + & + & \\
\hline Enterococcus & 5 & 2 & & + & + & + & + & + \\
\hline Micrococcus & 2 & 2 & & + & + & + & + & + \\
\hline Brevibacterium & 1 & 1 & & + & + & & + & + \\
\hline Leucobacter & 3 & 1 & & + & + & & + & + \\
\hline Lysinibacillus & 4 & 1 & & + & & + & + & + \\
\hline Okadaella & 1 & 1 & & + & & + & & + \\
\hline Rhodococcus & 10 & 1 & + & + & + & & & + \\
\hline Shigella & 1 & 1 & + & & & + & & + \\
\hline Tessaracoccus & 3 & 1 & & + & & + & + & + \\
\hline
\end{tabular}

*Bacteria were identified by 165 rDNA sequencing and were considered as 'weakly' or 'highly' adherent according to their ability to detach from the stainless steel chips: bacteria recovered after three washing steps were qualified as 'weakly adherent', whereas those recovered after sonication and scrapping were considered as 'highly adherent'. 

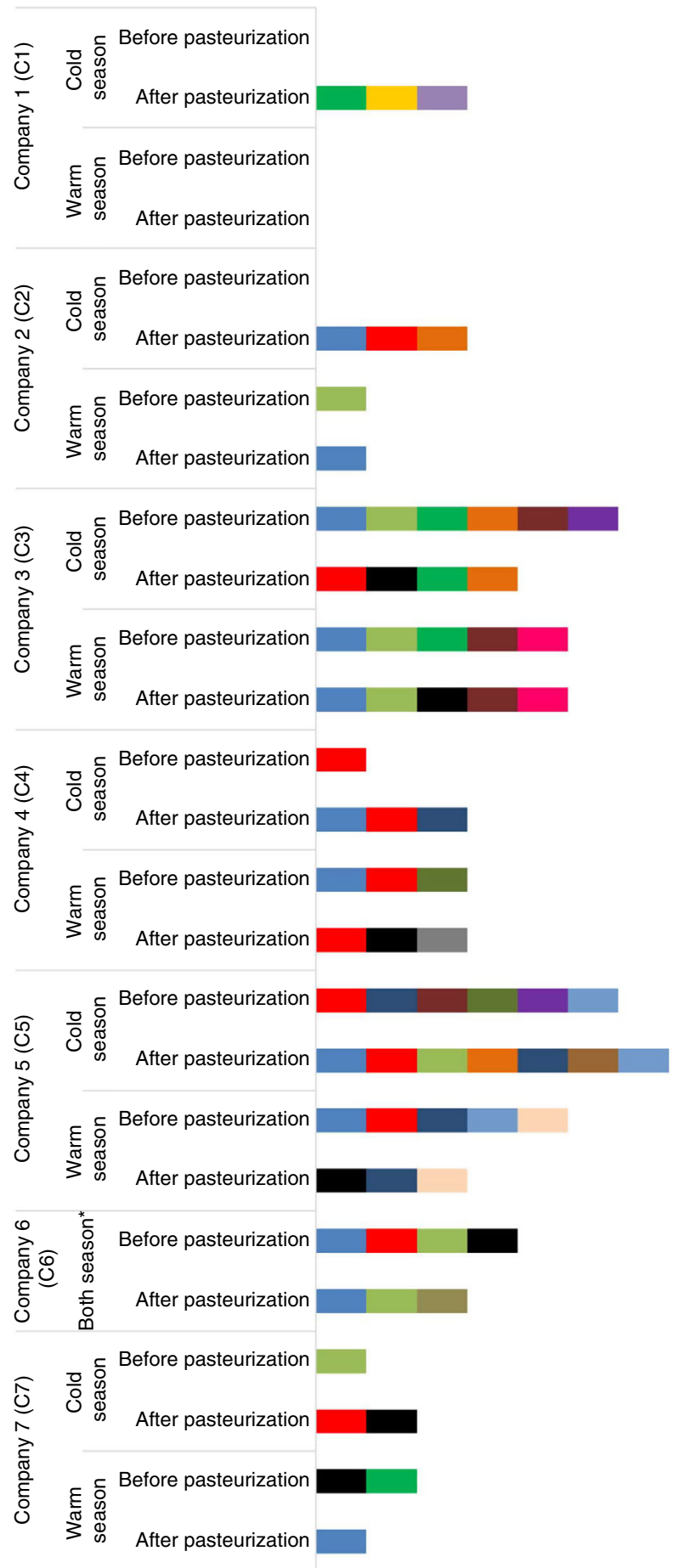

belonging to the Bacillus genus, in order to have further data related to spore-forming bacteria. Indeed, in other food ssuch as milk, it is generally recognized that biofilms can serve as reservoirs for bacterial spores, which can slough off and further contaminate food products (McHugh et al. 2017). Sixty-five isolates were, therefore,
Figure 1 Bacterial genera recovered from the stainless steel chips in the different egg breaking companies (C1-C7) according to the season (warm and cold) and to the location in the process (before and

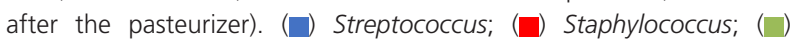
Bacillus; $(\square)$ Kocuria; $(\square)$ Microbacterium; $(\square)$ Rothia; $(\square)$ Corynebacterium; $(\square)$ Dietzia; $(\square)$ Enterococcus; $(\square)$ Micrococcus; $(\square)$ Brevibac-

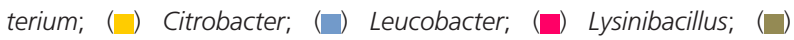
Okadaella; $(\square)$ Rhodococcus; $(\square)$ Shigella; ( ) Tessaracoccus. $\left({ }^{*}\right)$ Chips from the company $\mathrm{C} 6$ were maintained in the pipelines during the consecutive warm and cold seasons.

further investigated regarding their adhesion, their growth potential and their ability to induce whole egg spoilage at refrigerated temperature.

In vitro adhesion of 65 highly adherent isolates recovered in the industrial pipelines of the seven egg processing companies

The whole bacterial collection was able to adhere on stainless steel after $2 \mathrm{~h}$ contact with the support at $30^{\circ} \mathrm{C}$. The adhesion capacities were evaluated between 1.5 and $5.6 \log \mathrm{CFU}$ per $\mathrm{cm}^{2}$ depending on the isolate. The average adhesion values of the controls (internal standards) were, respectively, $4.3 \pm 0.3 \log \mathrm{CFU}$ per $\mathrm{cm}^{2}$ and $3.0 \pm 0.4 \log \mathrm{CFU}$ per $\mathrm{cm}^{2}$ for the strain C43 (a mesophilic B. cereus group strain), and the strain BW1 (a psychrotrophic B. cereus group strain isolated from a spoiled liquid egg product (Baron et al. 2007). All the isolates, pregrown for $18 \mathrm{~h}$ at $30^{\circ} \mathrm{C}$ in BHI-YE and 100-fold diluted in $9 \mathrm{~g} \mathrm{l}^{-1} \mathrm{NaCl}$, were not at the same concentration at the beginning of the adhesion test. The concentrations varied from 5.4 to $8.9 \log \mathrm{CFU}$ per ml. That is the reason why the results were expressed as the ratio between the number of adherent cells and the number of cells inoculated on the chips (Fig. 2).

The adhesion ratios were between $0.25 \mathrm{~cm}^{2} \mathrm{ml}^{-1}$ for the lowest adhesion values and $1.15 \mathrm{~cm}^{2} \mathrm{ml}^{-1}$ for the highest adhesion values. The adhesion rates of Kocuria sp. and Rothia sp. isolates $\left(>0.8 \mathrm{~cm}^{2} \mathrm{ml}^{-1}\right)$ was significantly higher than for the other genera. Staphylococcus sp., Microbacterium sp., Bacillus sp. and Lysinobacillus sp. isolates showed similar behaviours, with average adhesion ratios close to $0.6 \mathrm{~cm}^{2} \mathrm{ml}^{-1}$. A high diversity was observed inside the Streptococcus genus. The isolates of this genus exhibited significantly lower adhesion rate than the isolates of most of the other genera (Fig. 2).

The analysis of the behaviour or the whole bacterial collection did not reveal any significant influence of the season (cold or warm) and of the company on the level of adhesion. The location in the process (before or after pasteurization) did not also significantly impact the adhesion capacities $(P>0.05)$. 


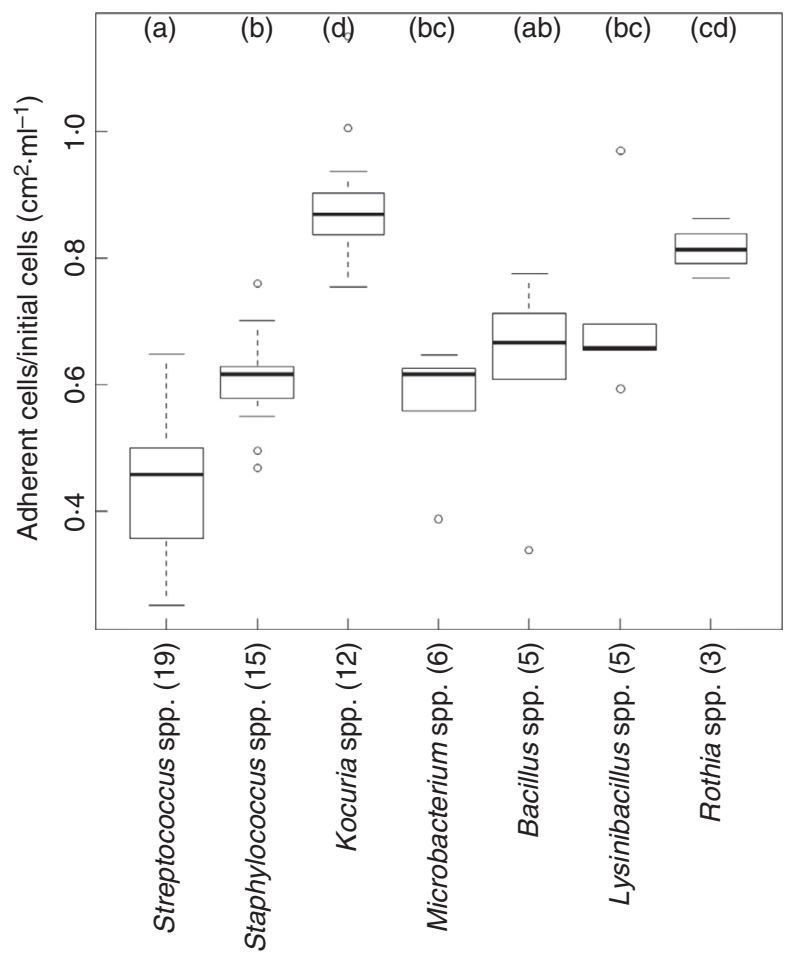

Figure 2 In vitro adhesion of the isolates of the main bacterial genera recovered from the seven egg breaking pipelines (the number of isolates is given between brackets). For each boxplot, the same letter indicates no significant difference between the genera $(P>0.05)$.

In vitro growth and spoilage potential of 65 highly adherent isolates recovered in the industrial pipelines of the seven egg processing companies

Of the 65 isolates studied, $14(22 \%)$ and $12(18 \%)$ were able to grow at $10^{\circ} \mathrm{C}$ in a liquid optimum medium (BHIYE) and on a solid egg-based medium respectively (Table 2). Only 1 over 19,1 over 15,1 over 12 and 1 over 6 isolates of Streptococcus sp., Staphylococcus sp., Kocuria sp. and Microbacterium sp. genera, respectively, were able to grow at $10^{\circ} \mathrm{C}$ in the optimal medium. Optimal growth was observed for all Bacillus sp. and Lysinobacillus isolates (5 over 5), contrary to Rothia sp. isolates, which were not able to grow at $10^{\circ} \mathrm{C}$ under the tested conditions. The average level of population was $8 \cdot 0 \pm 0 \cdot 5 \log \mathrm{CFU}$ per $\mathrm{ml}$ for all the isolates expressing growth at this temperature (data not shown).

The enzymatic activities were quantitatively evaluated on solid egg-based medium by measurement of the area of the halos surrounding the bacterial colonies after incubation at $10^{\circ} \mathrm{C}$. Streptococcus sp., Staphylococcus sp. and Kocuria sp. isolates did not express any enzymatic activities (Table 2). Specific enzymatic activities were between 10 and 24 depending on the isolate. Most of them were early detected (after as quickly as 5 days) (Fig. 3).

Amongst the 14 isolates which were able to grow at $10^{\circ} \mathrm{C}$, only seven isolates, mainly of the Bacillus sp. and Lysinobacillus sp. genera, were able to induce whole egg spoilage. The spoilage appeared after 12-16 days of incubation at $10^{\circ} \mathrm{C}$.

\section{Discussion}

In the processing equipment used for the manufacture of egg products, distinct but connected phases may authorize microbial growth: the liquid phase, in which planktonic cells proliferate, and the solid/liquid interface where cells can attach and potentially form biofilms. Each phase constitutes a unique habitat and cells can move from one to the other, depending on their physiological state, the nutrient availability and the shear forces, as already described in other food sector such as milk (Marchand et al. 2012). Although some data are available on the bacterial contaminants of the liquid phase (Protais et al. 2006; Hidalgo et al. 2008; Miller et al. 2010; Techer et al. 2015), little is known on the bacteria present at the interface. This bacteria may contaminate the egg products and further lead to sanitary and/or spoilage issues. This study

Table 2 Characterization of the bacterial isolates recovered from French industrial egg product pipelines regarding (i) growth in liquid optimal medium (BHI-YE) and on solid egg-based medium; (ii) enzymatic activity on solid egg-based medium and (iii) whole egg spoilage ability

\begin{tabular}{llllll}
\hline Bacterial genus & $\begin{array}{l}\text { Number of } \\
\text { isolates }^{*}\end{array}$ & $\begin{array}{l}\text { Growth in } \\
\text { optimum medium }\end{array}$ & $\begin{array}{l}\text { Growth on solid } \\
\text { egg-based medium }\end{array}$ & $\begin{array}{l}\text { Enzymatic } \\
\text { activity }\end{array}$ & $\begin{array}{c}\text { Whole egg } \\
\text { spoilage }\end{array}$ \\
\hline Streptococcus sp. & 19 & 1 & 1 & 0 & 0 \\
Staphylococcus sp. & 15 & 1 & 1 & 0 & 0 \\
Kocuria sp. & 12 & 1 & 1 & 0 & 0 \\
Microbacterium sp. & 6 & 1 & 1 & 3 & 0 \\
Bacillus sp. & 5 & 5 & 5 & 3 & 3 \\
Lysinobacillus sp. & 5 & 5 & 0 & 0 & 4 \\
Rothia sp. & 3 & 0 & 12 & 9 & 0 \\
Total & 65 & 14 & & & 7 \\
\hline
\end{tabular}

* Results are expressed as the number of positive isolates for each test. 


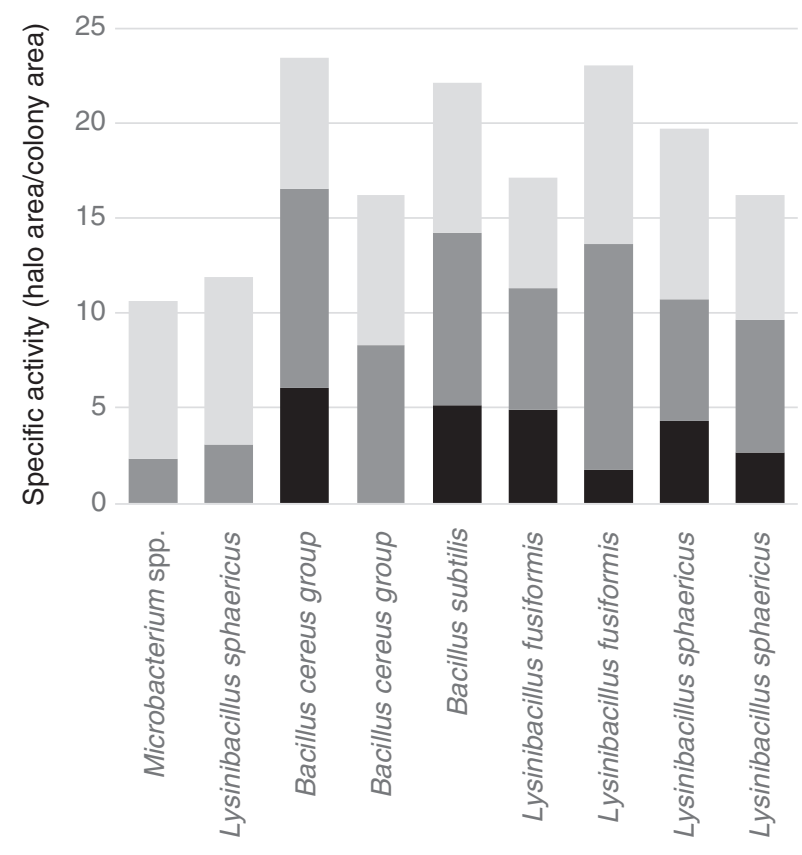

Figure 3 Specific enzymatic activities of the bacterial isolates recovered from French industrial egg product pipelines on agar egg-based medium at $10^{\circ} \mathrm{C}$. Enzymatic activities are expressed as specific activities corresponding to the ratio between the halo area and the colony area. $(\square)$ day 5; $(\square)$ day 8; $(\square)$ day 15.

aims at better understanding the specific adherent bacteria able to cause whole liquid egg spoilage by investigating the bacterial diversity in the French egg processing industry and to explore the stainless steel adhesion and the spoilage potential of the bacteria recovered on the industrial surfaces.

The most frequently isolated bacteria coming from the industrial surfaces were Gram positive bacteria belonging to the Firmicute and Actinobacteria phyla. Streptococcus, Staphylococcus and Bacillus genera are common contaminants installed in the form of biofilms in the food industry, such as the dairy industry (Marchand et al. 2012; Cherif-Antar et al. 2016). Kocuria sp. has also been reportedto enter into the composition of industrial biofilms in the food industry (Cherif-Antar et al. 2016), but it is mostly identified as dominating in the biofilms formed on the stainless steel material of domestic kitchens (Moen et al. 2015). All the other microbial types identified in this work (with the exception of Okadaella sp.) have also already been reported as biofilm components in the food industry (Sharma and Anand 2002; Marchand et al. 2012; Jahid and Ha 2014; Møretrø et al. 2015; Cherif-Antar et al. 2016) in the environment (Shpigel et al. 2015) or in a medicine context (Muir and Tan 2008).

Most of the bacteria identified on the industrial surfaces belong to several genera, which highlight the multispecies character of the adherent cells present on the surfaces of the French egg processing companies submitted to this analysis. These results are coherent with those reported in literature. Indeed, it is generally admitted that surface-associated communities are usually complex associations of different species, which interact in different ways to constitute a complex and dynamic network (Di Ciccio et al. 2015). Such interactions play a key role in shaping biofilm architecture and are responsible for specific functions. In particular, an increasing number of studies have reported that multispecies biofilms appear to be more resistant to antimicrobial activity than their mono-species counterparts (Di Ciccio et al. 2015).

The main adherent bacteria were identified at both locations (before and after pasteurizer), suggesting that the pasteurization process does not select specific bacteria among those present in the raw egg product. At the opposite, in dairy industry, Marchand et al. (2012) reported that the heat treatment influences the type of biofilm (mono- or multispecies) encountered. While streptococci form predominantly monospecies biofilms on heat exchanger plates in the downstream side of pasteurizers, Pseudomonas sp. are more likely to produce multispecies biofilms on the walls of milk cooling tanks or pipelines prior to heat processing. The development of a single-species biofilm may occur due to the fact that heat-sensitive species are killed during pasteurization, leaving only heat-resistant species such as Streptococcus bovis and Streptococcus thermophilus (Marchand et al. 2012). To our knowledge, no literature is available on the type of contaminants that may develop on the industrial surfaces of egg processing. It is then difficult to understand why the pasteurization had no effect on the type of contaminant present on the industrial surfaces.

The main adherent bacteria were also identified at both seasons. In an exhaustive study on the microbial quality of whole egg products collected in the main French egg product industry, Protais et al. (2006) have shown that the season affects the level of the bacterial contamination of whole egg products. The contamination of raw liquid whole egg was higher in summer in terms of microbial load and bacterial diversity. In pasteurized egg products, the contamination level was globally higher in summer than in autumn, mainly due to the higher prevalence of Pseudomonas and psychrophilic bacteria. In winter, Enterococcus and Streptococcus were dominant (Protais et al. 2006). However, these phenomena are of a concern to the egg products themselves and not the industrial surfaces. We could then assume that there is no link between the adherent bacteria and the seasonal effect observed in the study of Protais et al. (2006).

The adhesion of bacteria is the first step for biofilm establishment on industrial surfaces. The ability of 65 
representative isolates to individually adhere on a surface has shown variable adhesion levels on stainless steel chips. This variability was independent of the origin of the isolates (season, company or location in the process) but was dependant on belonging to a particular genus. Three groups were highlighted with a strongly adherent bacterial group composed of Kocuria sp. and Rothia sp. isolates; an intermediary adherent bacterial group formed by Staphylococcus sp. Microbacterium sp. Bacillus sp. and Lysinibacillus sp. isolates and a third group with Streptococcus sp. isolates (i) showing high diversity in terms of adhesion and (ii) involving isolates with lower adhesion levels than the other genera tested. Comparison with literature data is difficult since the methodology differs from one study to another. In addition, it is already reported that bacterial adhesion is highly variable according to several factors such as surface composition, microbial load of the food, association and type of micro-organism, temperature, $\mathrm{pH}$ and nutrient availability (Jahid and Ha 2014).

The spoilage potential of the bacterial collection was investigated in order to evaluate the issue that adherent bacteria may represent the final food product (liquid whole egg). Amongst 65 isolates belonging to seven bacterial genera, only seven Lysinibacillus and Bacillus isolates were able to spoil liquid whole egg to give rise to a white slurry cream. This type of spoilage is one of the main issues encountered during whole egg product storage (F. Baron, personal communication). In egg products, two parameters are crucial for evaluating the spoilage risk: the ability of the bacteria to grow at low temperature and their ability to produce enzymes, which may lead to serious defects in the final products. Our study has shown that the isolates are able to grow at $10^{\circ} \mathrm{C}$ are not systematically able to spoil the whole egg and that all the spoilers, mainly of the Bacillus and Lysinibacillus genera, expressed high levels of enzymatic activities. In addition, the isolates harbouring low enzymatic activities at $10^{\circ} \mathrm{C}$ were not associated with spoilage. These results suggest that the level of enzymatic activities is a key determinant for whole egg spoilage.

The involvement of Bacillus sp., and notably of bacteria belonging to the $B$. cereus group, in the spoilage of egg products has been frequently reported (Baron et al. 2007; Techer et al. 2014a, 2014b). These bacteria are known to produce various types of enzymes which may lead to various food degradation and spoilage, like sweet curdling and bitterness of milk, decreasing the shelf-life of the products and, therefore, resulting in significant economic loss for food producers (Majed et al. 2016). To our knowledge, the spoilage issue due to Lysinibacillus sp. has never been described in the literature. However, this spoilage potential is not surprising; it is well-known that these aerobic spore-formers, as bacteria of the $B$. cereus group, are able to produce various extracellular hydrolytic enzymes, such as proteases, lipases and lecithinases, which are known to cause milk defects (De Jonghe et al. 2010).

Our results confirm (i) the assumption that adherent cells are source of spoilage in the egg processing industry and (ii) the involvement of hydrolytic enzymes in the spoilage of egg products.

The present study is the first report on the microbial communities present on the surfaces of French egg processing companies. The industrial surfaces are mainly colonized by multispecies Gram positive bacteria. Even if a high bacterial diversity was observed on the surface of some industrial pipelines, the spoilage of whole egg was only due to isolates exhibiting high levels of enzymatic activities, mainly of Bacillus and Lysinobacillus genera. The present study highlights the need to control adherent bacteria in the egg processing industry, in order to limit spoilage issues.

\section{Acknowledgements}

Authors are grateful to the companies belonging to the Association pour le Développement de la Recherche sur les Ovoproduits dans l'Ouest (ADRO-Ouest) for their contributions (acceptance and technical support for fixing the stainless steel chips inside the industrial pipelines).

\section{Conflict of Interest}

The authors have no conflicting financial interests.

\section{References}

Anton, M., Lechevalier, V. and Nau, F. (2016) From eggs to egg products. In Handbook of Food Science and Technology 3 eds. Jeantet R., Croguenne T., Schuck P. and Brulé G. pp. 115-143. Hoboken, NJ: John Wiley \& Sons.

Baron, F. and Jan, S. (2011) Egg and egg product microbiology. In Improving the Safety and Quality of Eggs and Egg Products. Vol. 1: Egg Chemistry, Production and Consumption eds. Nys Y., Bain M. and Van Immerseel F. pp. 330-350. Cambridge, UK: Woodhead Publishing Limited.

Baron, F., Cochet, M.F., Ablain, W., Grosset, N., Madec, M.N., Gonnet, F., Jan, S. and Gautier, M. (2006) Rapid and cost-effective method for microorganism enumeration based on miniaturization of the conventional platecounting technique. Lait 86, 251-257.

Baron, F., Cochet, M.F., Grosset, N., Madec, M.-N., Briandet, R., Dessaigne, S., Chevalier, S., Gautier, M. et al. (2007) Isolation and characterization of a psychrotolerant toxin producer, Bacillus weihenstephanensis, in liquid egg products. J Food Prot 70, 2782-2791.

Cherif-Antar, A., Moussa-Boudjemâa, B., Didouh, N., Medjahdi, K., Mayo, B. and Flórez, A.B. (2016) Diversity and biofilm-forming capability of bacteria recovered from 
stainless steel pipes of a milk-processing dairy plant. Dairy Sci Technol 96, 27-38.

De Jonghe, V., Coorevits, A., De Block, J., Van Coillie, E., Grijspeerdt, K., Herman, L., De Vos, P. and Heyndrickx, M. (2010) Toxinogenic and spoilage potential of aerobic spore-formers isolated from raw milk. Int J Food Microbiol 136, 318-325.

Di Ciccio, P., Vergara, A., Festino, A.R., Paludi, D., Zanardi, E., Ghidini, S. and Ianieri, A. (2015) Biofilm formation by Staphylococcus aureus on food contact surfaces: relationship with temperature and cell surface hydrophobicity. Food Control 50, 930-936.

EFSA Biohaz Panel (EFSA Panel on Biological Hazards). (2014) Scientific opinion on the public health risks of table eggs due to deterioration and development of pathogens. EFSA J 12, 3782.

Guinebretière, M.H., Broussolle, V. and Nguyen-The, C. (2002) Enterotoxigenic profiles of food-poisoning and food-borne Bacillus cereus strains. J Clin Microbiol 40, 3053-3056.

Hidalgo, A., Rossi, M., Clerici, F. and Ratti, S. (2008) A market study on the quality characteristics of eggs from different housing systems. Food Chem 106, 10311038.

Itavi. (2018) Faites le point sur les marchés mondiaux, européens et français des oeufs et ovoproduits. Note de conjoncture poules pondeuses.

Jahid, I.K. and Ha, S.D. (2014) The paradox of mixed-species biofilms in the context of food safety. Compr Rev Food Sci Food Saf 13, 990-1011.

Jan, S., Brunet, N., Techer, C., Le Maréchal, C., Koné, A.Z., Grosset, N., Cochet, M.F., Gillard, A. et al. (2011) Biodiversity of psychrotrophic bacteria of the Bacillus cereus group collected on farm and in egg product industry. Food Microbiol 28, 261-265.

Jan, S., Bouchon, L., Techer, M.-C., Grosset, N., Gonnet, F., Cochet, M.F., Gautier, M. and Baron, F. (2014) Kinetic Expression of Spoiling Enzymes by a Comprehensive Bacillus cereus Group Collection Coming from the French Egg Breaking Industry. Nantes, France: FoodMicro.

Lechevalier, V., Croguennec, T., Anton, M. and Nau, F. (2011) Processed egg products. In Improving the Safety and Quality of Eggs and Egg Products eds. Nys Y., Bain M. and Van Immerseel F. pp. 538-581. London, UK: Woodhead Publishing.

Majed, R., Faille, C., Kallassy, M. and Gohar, M. (2016) Bacillus cereus biofilms - same, only different. Front Microbiol 7, 1054.

Marchand, S., Block, J.D., Jonghe, V.D., Coorevits, A., Heyndrickx, M. and Herman, L. (2012) Biofilm formation in milk production and processing environments; influence on milk quality and safety. Compr Rev Food Sci Food Saf 11, 133-147.

McHugh, A.J., Feehily, C., Hill, C. and Cotter, P.D. (2017) Detection and enumeration of spore-forming bacteria in powdered dairy products. Front Microbiol 8, 109.

Miller, P., Haveroen, M.E., Solichová, K., Merkl, R., McMullen, L.M., Míková, K. and Chumchalová, J. (2010) Shelf life extension of liquid whole eggs by heat and bacteriocin treatment. Czech J Food Sci 28, 280-289.

Moen, B., Røssvoll, E., Måge, I., Møretrø, T. and Langsrud, S. (2015) Microbiota formed on attached stainless steel coupons correlates with the natural biofilm of the sink surface in domestic kitchens. Can J Microbiol 62, 148-160.

Møretrø, T., Sharifzadeh, S., Langsrud, S., Heir, E. and Rickard, A.H. (2015) Coaggregation between Rhodococcus and Acinetobacter strains isolated from the food industry. Can J Microbiol 61, 503-512.

Muir, R.E. and Tan, M.-W. (2008) Virulence of Leucobacter chromiireducens subsp. solipictus to Caenorhabditis elegans: characterization of a novel host-pathogen interaction. Appl Environ Microbiol 74, 4185-4198.

Protais, J., Gerault, P., Queguiner, S., Boscher, E., Chidaine, B., Ermel, G., Rivoal, K., Salvat, G. et al. (2006) Identification and behaviour of modified bacteria in the matrix of liquid whole eggs. Sci Techn Avicoles 57, 4-13.

Sharma, M. and Anand, S.K. (2002) Biofilms evaluation as an essential component of HACCP for food/dairy processing industry - a case. Food Control 13, 469-477.

Shpigel, N.Y., Pasternak, Z., Factor, G. and Gottlieb, Y. (2015) Diversity of bacterial biofilm communities on sprinklers from dairy farm cooling systems in Israel. PLoS ONE 10, e0139111.

Techer, C. (2015) Altération des entremets à base d'ovoproduits: bactéries impliquées et mécanismes en jeu (Doctoral dissertation). Retrieved from database these.fr (Order no. 2015NSARB265).

Techer, M.C., Baron, F. and Jan, S. (2014a) Microbial spoilage of eggs and egg products. In Encyclopedia of Food Microbiology pp. 439-445. Boston, MA: Academic Press.

Techer, C., Baron, F., Delbrassinne, L., Belaïd, R., Brunet, N., Gillard, A., Gonnet, F., Cochet, M.F. et al. (2014b) Global overview of the risk linked to the Bacillus cereus group in the egg product industry: identification of food safety and food spoilage markers. J. Appl Microbiol 116, 1344-1358.

Techer, C., Daoud, A., Madec, M.N., Gautier, M., Jan, S. and Baron, F. (2015) Microbial quality of industrial liquid egg white: assumptions on spoiling issues in egg-based chilled desserts. J Food Sci 80, M389-M398.

Van Houdt, R. and Michiels, C. (2010) Biofilm formation and the food industry, a focus on the bacterial outer surface. $J$ Appl Microbiol 109, 1117-1131. 